Euskal ikerketen aldizkaria | Revue d'études basques |

Revista de estudios vascos | Basque studies review

$7 \mid 2002$

Numéro VII

\title{
Oharmenaz ohartu eta muga galdu
}

\section{Miren Lourdes Oñederra}

\section{OpenEdition}

Journals

Édition électronique

URL : http://journals.openedition.org/lapurdum/1020

DOI : 10.4000/lapurdum. 1020

ISSN : 1965-0655

Éditeur

IKER

Édition imprimée

Date de publication : 1 octobre 2002

Pagination : 259-270

ISBN : 2-86781-321-2

ISSN : $1273-3830$

\section{Référence électronique}

Miren Lourdes Oñederra, « Oharmenaz ohartu eta muga galdu », Lapurdum [Linean], 7| 2002, Sarean emana---an 01 juin 2009, kontsultatu 01 mai 2019. URL : http://journals.openedition.org/ lapurdum/1020 ; DOI : 10.4000/lapurdum.1020 


\title{
Oharmenaz ohartu eta muga galdu
}

\author{
Miren Lourdes OÑEDERRA
}

\author{
Euskal Herriko Unibertsitatea \\ ("Euskal ahoskera: ikerketen nondik norakoa" Mintegia \\ Baiona, 2001-XII-12)
}

\section{Aldez aurretik}

Txikitan ikastolan "Mendizaleak aurrera" hitzekin hasten zen kantua abesten genuen, besteak beste, eta bazuen kantu horrek lerro-zati bat nik (eta nire ikaskide askok ere bai ziurrenera) "mendi gora maletakin" ahoskatzen nuena, ahalik eta ongien egokituz musikari nire ahotsa eta irudikatuz euskaldun gizajo haiek, beste euskaldunak esnatzera nola zihoazen mendi gora kartoizko maleta pobre eta astunekin, izerdi patsetan... Gerora jakin dut, kantuak zioena "mendi gora maldetatik" zela, baina orduan ezinezkoa zitzaidan hori ulertzea, niretzat, nire orduko hiztegi txikiagoaren arabera, malda guztiak "aldapa" deitzen baitziren.

Nahi dena edo behar dena edo ahal dena entzuten da, barneratzen da. Goikoa muturreko kasua da, hiztegiaren mugek azaltzen dutena : nire orduko hiztegian ez zegoen "malda" eta nik (nire oharmenak), fonetikari iruzur eginez, "maldetatik" seinale akustikoan "maletakin" zegoela erabaki nuen. Fonetikoki aldea ez da handiegia eta zentzuaren aldetik gauzak ongi moldatzen ziren horrela. Niretzat, "maldetatik" ezinezko gertakizuna zen orduan.

Berbera da funtsa baita horren muturreko ez diren kasuetan ere, baita truke edo ordezkatze lexiko eta gramatikalak (maldetatik $\rightarrow$ maletakin) gertatzen ez direnean ere, beti gertatzen da : ez dugu entzuten fonetikoki (fisikoki) gertatzen dena, linguistikoki nahi duguna, behar duguna, ahal duguna baizik. "Ongi" entzuten dugunean ere, alegia, hitz-nahasterik ez denean ere, ez da entzuten gertatzen den den-dena edo gertatzen dena baino gehiago entzuten da. Baldintza desberdinen arabera (ez dugu orain hori analizatzeko lekurik), gerta daiteke ekoiztu ez dena eranstea. Esate baterako ingelesez hiztun batek [stop] esan eta guk /estop/ entzuten dugunean eransketa bat egiten dugu : ahoskatu ez den [e-] bat entzun dugu (ik. Jauregi/Oñederra 2002). Beste batzuetan ezberdin ahoskatu dena berdindu egiten du gure oharmenak, horregatik izu ([isu]) edo hizlari [izlari] hitzetako txistukariak berdin-berdin entzuten ditugu, fisikoki lehena ahoskabez eta bigarrena ahostunaz gertatzen direnean ere.

Hizketa ekoiztean ere beste horrenbeste gertatzen da, /oאo/ esan nahi eta [ojאo] ebakitzen denean, esaterako.

Oraingo ikerlarien artean, makinen lilura eta bestelakoak direla, gero eta handiagoa da fisikoki gertatzen dena jakiteko grina eta hori ongi dago : oso ongi. 
Zalantzarik gabe beharrezkoa da, baina ez da nahikoa ; kontua jartzen ez bada, egokia, zuzena ere ez da.

Fonetika akustikoan dabiltzanek ederki aski dakiten gauza da makinek ongiegi entzuten dutela. Hizketaren aldagarritasun mugagabea, guk askotan hautematen ere ez duguna, garbi jaso eta neurtzen dute. Makinek ez dute gure gaitasun fonologikoak eta gure hizkuntzaren ezagutzak ematen diguten abilidade bat, gizakiak oso gaztetan lortzen omen duena, Oliver Sacksen $(1996,128)$ hitzetan perceptuak constancy :

We achieve perceptual constancy -the correlation of all the different appearances, the transforms of objects-- very early, in the first months of life. It constitutes a huge learning task, but is achieved so smoothly, so unconsciously, that its enormous complexity is scarcely realized (though it is an achievement that even the largest supercomputers cannot begin to match).

Bestalde, makinek ez dute entzuten guk (fisikoki gertatu gabe ere) entzuten dugun zenbait gauza (gogora goragoko adibideak). Fonetika akustikoak eta tresnabidezko lanak hori erakusten digute, besteak beste. Hortxe dago, nire ustez, makinen laguntzaren alderdirik interesgarriena : akustikoki gertatu denetik guk hautematen dugunera dagoen aldea, gure oharmenaren beregaintasunaren neurria eta nolakotasuna ezagutzeko ematen digun bidea.

Seinale fisikoarekiko beregaintasunaz ari naiz hemen : egungo tresnabidezko ikerketak berresten du eta frogatzen -Baudouin de Courtenay, Kruszewski edo Sapir batek oso garbi arrazoitu zutena-- seinale akustikoak ez duela erabat baldintzatzen entzuleak jasotzen duena eta, horregatik, fonetikak bakarrik ez duela inoiz agortuko ahoskeraren analisia.

Hortik aurrera zenbait gogoeta dakartzat, pentsa-bide, iradokizun izan nahi luketenak. Izan ere, ez dakigu asko : ez diogu honela begiratu gaiari, ez gaude ohituta, ez dago tradiziorik linguistikaren jakintza alor honetan. Nire mugak, noski, jakintza alorrarenak baino are estuagoak dira, horregatik eta ez da erretolika huts, galderak dakartzat, erantzunak baino areago, programak, hemendik aurrerako ikerplanak behar luketenak. Hain zuzen ere, mandatua XXI. mendean barrena gu baino luzeago iraungo duten mintegi honetako partaide gazteagoengana iristea nahi nuke.

Nire aldetik saiatu naiz, nire euskal fonologiari eta fonologia orokorrari buruzko ikerketetan, eskolak prestatzean eta ematean, orain ikasleentzako idazten ari naizen eskuliburu batean nabilela, sortu zaizkidan gaiak, galderak zenbait ardatz teorikoren inguruan atalkatzen : gainera, ardatz teoriko horietan euskararen inguruko ikergalderak josi ditut.

\section{Oharmena eta fonologiaren historia}

Fonologiak, bere historian zehar, memento batetik aurrera oharmena alde batera uzten du : ez da erabiltzen jakintza (fonologia bera, alegia) gorpuzteko, teoria eraikitzeko. Ez da, noski, errealitatea ukatzen zaiola, baina kausalitatea, hiztunaren kontzientzia, intentzioa eta horrelakoak arrazoibide ez zientifikotzat jotzen dira. 
Fonetikari eta, batik bat, fonologilarien artean, oharmenaz irakurtzeko XIX. mendeko azken aldera edo XX.eko heterodoxoengana jo beharrean gara (eskola handietatik at dabiltzanengana alegia).

Oharmenaren uzteak fonetikatik aldentzearekin izan duen zerikusia ez da gauza erraza baina ez da ahaztutzeko kontua, oraindik dirauten ondorio luze eta sakonak izan baititu. Ahalik eta laburren esan dezadan oraingoz beherago luzatuko duguna : oharmenak ahoskeraren ikerketetan estatusa galtzetik dator, neurri handi batean, fonetika eta fonologiaren arteko muga lainotzea ; horrek alor bien arteko beregaintasuna ahultzen du eta, horrela, elkarlana eragozten.

Fonologiaren historian zerbait izan bada fonetikarekiko aldentzearen seinale argi, artxifonema izan da. Fonologiaren sorkuntzarik bitxienetakoa da artxifonema delakoa. Duela gutxi tesi aurkezpen batean esateko aukera izan nuen bezala (tesigile fonetikariaren lasaitasunerako), errealitatean, benetako munduan, ez dago artxifonemarik. Artxifonemarena estrukturalisten fonema definizioaren reductio ad absurdum bat da, baina, gezurra badirudi ere oraindik mugaz handikako estatuko akademian behintzat bizirik dirauen ikuspegia da eta lasai esaten dizute hitz azkeneko edo kontsonante aurreko dardarkaria ez dela ez [r], ez [r], /R/ artxifonema baizik. Asmakizun horrekin beren fonema definizioa salbatu zuten estrukturalista europarrek. Beste fonemekiko diferentziak bakarrik gauzatzen duen fonema abstraktua ez baitzetorren bat, fonema biren arteko diferentzia zenbait ingurunetan deuseztatzearekin. Gogora dezagun estrukturalistek inspirazio-iturri zeukaten Saussure $(1916,13)$ :

Ce qui importe dans le mot, ce n'est pas le son lui même, mais les différences phoniques qui permettent de distinguer ce mot de tous les autres, car ce sont elles qui portent, la signification.

Ikuspegi horretan fonema hizketa hots baten ezaugarri bereizleek osatzen dute (Europako estrukturalismoa), edo banaketa osagarrian gertatzen diren hotsen bildumak (Ameriketako estrukturalismoa). Zein hots diren zehazki gertatzen direnak, aldaeren nolakotasun fisikoak, ezaugarri bereizleekin batera jazotzen diren ezaugarri osagarriek eta abarrek ez dute axola. Azken batean errealitate fonetikoak, berez, ez du asko axola.

Horrelako eta bestelako desegokitasunak zirela, Chomskyk (1964) estrukturalisten fonema definizioa kritikatu zuen, baina desegokitasunen arrazoietan gehiegi sakondu gabe eta Halleren (1959) laguntzarekin, fonema kendu egin zuen analisi fonologikotik. Beren funtsa zen ongi deskriba eta formaliza daitekeela hizkuntzaren ahoskera esaldien aurkezpen morfofonemikoa (morfemen oinarrizko forma zehazten duena) eta gertaera fonetikoa erregela fonologikoen bidez lotuta.

Fonema analisitik kentze horretan, ordea, bi ume joan zitzaizkion ontziko ur zikinarekin batera :

a) Sapir erabili eta aldarrikatu bazuen ere, ez zuen jaso Sapirrengan garrantzi handiko den bereizkuntza bat : hots txandakatze batzuk hauteman egiten dira

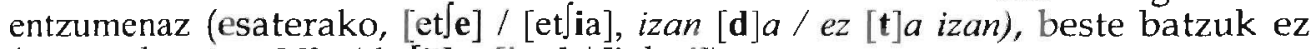
(esaterako, izan [d]a / ba[ð]a, [isu] / [izlari]). 
b) Sapirren beste bereizkuntza bat (XIX. mendeko Kruszewski bezalako fonologilariengan ere oso garrantzizko izan zena) : txandakatze mekaniko edo fonologiazkoak vs. morfologiarekin lotuak ${ }^{1}$.

Haatik, Chomskyrengandik aurrera edozein hots txandakatze fonologiaren eremuan sartzen da. Horixe izan da, XX. mendeko fonetika eta fonologiaren arteko distantzia handitu duten eragileen artean, gogorrenetakoa : bilakabide fonologikoak eta erregelak ez bereiztea. Baina elektriko / elektrizitate parean $\mathrm{k} / \mathrm{z}$ txandakatzeak, etxe / etxa- bezalako hitz-elkarketetako hots ordezkatzeek, gaztelerazko botón / euskarazko botoi egokitzapenak, eta abarrek ez dute inolako arrazoi fonetikorik sinkronikoki. Alferrik da hor fonologia-fonetika lotura bilatzea.

Haatik, kasu horietan loturarik ez izateak ez luke ilundu behar lotura badagoeneko zubia. Baina iluntzen du : nola den-dena fonologiaren zakuan sartzen den eta nola fonologiazkotzat hartu horietako batzuei ez zaien esplikazio fonetikorik aurkitzen, alde bat uzten da erabat fonetikaren esplikazio-gaitasuna fonologian (eta fonologiarena fonetikan).

Oharmena eta fonetika-fonologia erlazioa

Hasteko baieztapen bi :

- Fonetika oharmenaz ahaztuta, fonologiaz ahaztu da.

- Fonologia oharmenaz ahaztuta, esplikazioak bilatzeko eta, batik bat, emateko biderik gabe gelditu da.

Askotan gure analisi fonologikoetan esaten dugun gauza bakarra da delako hots unitate bat nola ezberdin ahoskatzen den ingurune ezberdinetan, gehienez ere deskribatze fonetiko soila emanda. Esaterako, $u r$ elementuaren azken / $\mathrm{r} /$ hori nola bakuna den bokal artean, baina anitza hitz-azken edo kontsonante-aurrean : cf. [urasko e[ð]an dut] eta [ur litroa e[ð]an dut].

Ez da azaltzen, aitzitik, zergatik den den bezalakoa /r/ hori agertoki bakoitzean eta, batez ere, ez da ia inoiz aztertzen eta azaltzen zergatik hiztunek berdintzat jotzen dituzten, adibidez esaldi horietako bakoitzaren barreneko [d] eta [ð] edo gorago aipatu ditudan izu eta hizlari hitzetako txistukariak eta $d a$ aditz-formaren /d/ kontsonante horzkari hori, desberdin ahoskatzen direnean ere (gogora izan [d]a / $b a[\partial] a$ adibideak).

Arrazoiaren zati bat ? : oharmenaren ordezkatzeak, ekoizpenean ere gertatzen direla, ordezkatze horiek entzuleak hiztun den bezainbatean egiten dituenak direla, alegia. Beraz, oharmena fonemikoa da, ekoizpena ere fonemikoa delako asmoan, intentzioan. Asmo fonemiko horien gainean, ordezkatze axalekoagoak gertatzen dira, baina horien ondorioak ez ditugu nahitaez hautematen.

Ordezkatze horiek arrazoi edo motibazio fonetikoa dute eta ez dira, berez, hizkuntzarenak hiztunarenak baizik. Bestela esan, ez dira kodearenak gizakiarenak baizik : unibertsalak dira, edozeinentzat baitira berdin fonetikaren baldintzak.

\footnotetext{
' Errepara ondoko aipuoi: "Nombre de linguistes bien intentionnés, travaillant avec d'excellents informateurs, n'ont obtenu, dans ce domaine, que des résultats décevants sans jamais supçonner que la faute en incombait à eux-mêmes et nullement à leurs informateurs. Il est extrêmement difficile, sinon impossible d'amener l'informateur à tenir compte de variations phonétiques purement mécaniques, dépourvues pour lui de toute réalité phonémique." (Edward Sapir, [1933] 1968, 168) eta, hamar orrialde beranduago: " Les transcriptions d'Alex sont, comme il est naturel, conçues dans un esprit nettement phonologique et c'est, dans une large mesure, en les étudiant que j'ai appris à estimer à sa juste valeur la différence psychologique entre un son et un phonème." (Ed'ward Sapir, op. cit., 178).
} 
Hizkuntza edo garai desberdinetan diferente izan daitezke, ordea, emankor diren ordezkatzeen multzoa eta ordezkatzeen elkarreraginak. Horien artean ordezkatze fonemikoek (hautematen direnek) hiztunak bere hizkuntzan entzuten duena eta ustez ekoizten duena murrizten dute, baina ez hori bakarrik : baita beste hizkuntzetan entzuten duena ere eta, halaber, erabat asmatuak diren hots eta hots kateen oharmena. Hiztunak bizirik dituen ordezkatze fonemiko horiek bere unibertso fonikoa zedarritzen dute.

\section{Oharmena eta fonema}

Hotsari buruzko lanetan oharmena aintzat hartzen ez bada (estatusik ez badu, ez bada gure teoriaren osagai) fonetika ezin da izan fonologiaren bigarren mailako laguntzaile besterik. Fonologilariok, gure proposamenak fisikoki neurtzeko erabiltzen dugun tresna, lanabesa.

Fonetikarientzat ere fonologia teoria iluna gertatzen, oharmenaren zubia present ez bada. Horregatik, sarri, fonema terminoa ez da erabiltzen edo, erabiltzen bada, ez dira garbi bereizten hots eta fonema kontzeptuak. Saiakera eta hitzaldi anitzetan ikusten da fonema "hots" esateko modu dotorea besterik ez dela, pisu teorikoa galdu duela : fonema oharmenetik bakarrik uler baitaiteke, fonema oharmena da teorikoki lehenengo gorpuztu zuen Baudouin de Courtenayk irakatsi bezala.

Fonema oharmena da, oharmenezko izakia da eta (entzumena bakarrik baliaturik) oharmena fonemikoa da. Kontsonante-bokalei dagokiela, fonemak entzuten ditugu, ez hotsak. Fonetikak, ordea, hotsak aztertzen ditu eta hortik hasten da gure analisia.

Fonologia egiteko entzulearen lekuan jarrita, analisia (entzuleak eta berarekin kokatzen den hizkuntzalariak egiten dutena) indukzioz gertatzen da, hotsetik abiatuta, datu fisiko enpirikotik abiatuta. Seinale akustikoaren deskodetzea den "entzute" hori egitate fonetikotik eduki linguistikoaren bila abiatzen da. Hotsetik barneranzko bide horretan, hiztun-entzuleak datorkion seinalean hotsak hautematen dituenean, hortxe, dago fonema. Orduan hiztunak hotsak fonema gisa irudikatzen ditu. Esan daiteke gertaturiko errealitate fonetiko akustikoak hiztunaren fonologi sistemarekin topo egiten duela, hizkuntzaren ordezkatze emankorrek zedarritzen duten hiztunaren unibertso fonikoarekin ${ }^{2}$.

Esan-aldi bakoitzaren oharmenean, hotsaren analisi fonemikoak hiztunaren unibertsoan posible diren aukera fonologiko guztiak irekitzen ditu. Gero, aukera horiek bat baino gehiago badira, analisi gramatikal eta lexikoak aukeratuko dute gertaldi horretarako egokiena (esaterako, [eria] ahoskatu denean, entzuleak fonemikoki hauteman /eria/ horri lexiko-gramatikalki dagokion interpretazioa zein den : //erea// 'brûlé(e)', 'quemada-o' ala //eria// 'peuple, village', ' pueblo').

Baditu, beraz, hiztunak beste zenbait baliabide, beste zenbait ezagutza, fonologiaz gainera, esana deskodetzen eta ulertzen laguntzen diotenak : funtsean, hizkuntzaren hiztegia eta gramatika sistema. Horick dira [eria] entzuten duen hiztunari //ere+a// ala //eri+a// esan den erabakitzen laguntzen diotenak. Fonologia hutsaz, bestelako testuinguru linguistiko edo ez-linguistikorik gabe, ezingo genituzke bereizi, /i/ fonema baita euskaraz eta hiztegiko /e/ gauzatzen duena

${ }^{2}$ Chomsky eta Halleren teoria dedukziozkoa da, estrukturalistena, berriz, indukziozkoa: hara hor gaizkiulertuaren arrazoi bat. Ikus David Stamperen "Yes, Virginia...", 3-4 
$(/$ ere $+\mathrm{a} /-->$ [eria]), /i/ baten gauzatzea dena (/eri+a/--> [eria]) bezalakoxea baita fisikoki.

\section{Oharmena eta prosodia}

Euskal "azentuari" buruzko ikerketak, biribildu eta osatzeko baino areago, ezinbesteko duen ikerbidea da hau nire ustez. Ezer gutxi egin da gure artean alor honetan eta, ez da, oro har, hizkuntzalaritzan gehien landu diren gai horietakoa ere. Ulertzekoa da, ez baita erraza oharmenaren azterketa eta, horren barruan, prosodiari dagozkion gaiak dira harrapagaitz eta irristakorrenak.

Lagungarri da, horregatik, galdera zehatzak aurkitzea bideak irekitzen hasteko garai honetan, galdera horiek funtsezko gaietatik oraindik oso urruti badaude ere ziurrenera.

García Calvok $(1989,37$. atala) bere ohiko zorroztasunaz adieratzen du ezaguna bezain interesgarri zaigun kontu bat. Gauza jakina da, izan ere, nola eramaten den lehen hizkuntzaren (L1) doinua bigarren hizkuntzara (L2). Maiz ikusi eta aipatu izan da, bigarren hizkuntzen ikasketetan, behar bezalako ahoskera lortzea dela ikasle gehien-gehienentzat zailena eta, ahoskeraren barruan, prosodia (doinua, erritmoa, azentu-kokatzea, eta abar). Nabaria izaten da nola L2 bereganatzean, hiztunak L2 ko hitzak bere Lleko ahoskeraz moldatzen dituen, batik bat bere Lleko prosodiaz. Ahoskeraz jabetzeko moldatzen direnen artean ere, gutxiengo erlatiboa osatzen dute, kontsonante eta bokalen ahoskeraz batera, L2ko prosodia menperatzen duten ikasleak. Izan ere, maila prosodikoa eta segmentalaren beregaintasuna frogatzen dute hotsak bai, baina prosodia bereganatzen ez duten L2ko hiztunek.

Halaz ere, norberaren jatorrizko hizkuntzaren prosodia "kentzea" horren zaila izanik, bizkaieradun, nafarreradunek, gipuzkeradunek berehala galdu dugu gure jatorrizko dialektoetako prosodia Euskara Batuarekin, Batua ikastean, Batua erabiltzean.

Zergatik?

a) eredu ahula delako (vs., esaterako, frantsesa, dudarik gabe eredu prosodiko indartsuenetakoa bere erregulartasunagatik)?

b) elebidun izanik (bi Ll ditugulako nolabait), erdarazkoa hartu dugulako EB ahoskatzeko orduan?

c) beste zerbait sortu dugulako, EB ez baita zehazki L2 bat guretzat (baizik eta ahoskerarik gabe-edo zetorkigun Ll baten aldaera bat ?

Hegoaldekook egiten duguna Iparraldekoek egiten dutenarekin erkatzeak berebiziko garrantzia du hemen ${ }^{3}$. Alde bakoitzean aztertu beharko litzateke hiztunek, Batuan ari direnean eta etxekoan ari direnean, zein bereizkuntza prosodiko egiten dituzten eta ea Batuan erdarazko eredua ala beste zerbait gertatzen den.

"Beste zerbait" hori (erdarazkoaren ordez edo erdarazkoarekin nahasirik) Hegoaldekoengan eta Iparraldekoengan aurkitzen bada ${ }^{4}$ Batuaren erregulartze

\footnotetext{
3 Gorka Elordieta fonologilariarekin batera abiatu dudan <Egungo euskal ahoskeraren analisia: gaztelera eta frantsesarekiko elkar-ukituen azterketa> (1/UPV/EHU00033.130-MA8025/2000) ikerketa proiektua bezalako asko beharko dira .

${ }^{4}$ Behin eta berriz aipatzen den azkenaureko azentua, esaterako.
} 
prosodikoa izan liteke... Baina oso oinarri ezberdinetatik abiatzen gara eta esango nuke ez dela lan arina izango horrelakoak isolatzea ${ }^{5}$.

\section{Oharmena eta elebitasuna}

Hemen euskararen azterketa egin dezakegunok, egin behar dugunok eta orain egin behar dugunok, lan esparru ezin hobea dugu : giza oharmenaren alorrean ekarpena egiteko aparta. Izan ere ezin gaitezke elebitasunak harrapatuago egon eta, gainera, hizkuntza birekiko elebitasunak... sistema fonologiko bi dituzten hizkuntza birekin dabil dantzan euskararen erabilera. Alegia, frantses-euskara eta gazteleraeuskara elebidun gara euskaradun gehien-gehienak (denak, neurriren batea) eta biografikoki, soziologikoki eta pragmatikoki elebitasun oreka eta neurri ezberdinak daude gure artean. Beraz, aztergaia ezin aberatsagoa da.

Hemen ere badugu bide teorikoari ekiteko moduko galdera andana : elebidunek bi sistema fonologiko beregain al dituzte ? Bi sistema baina ez beregain ? Sistema fonologiko zabalena duen hizkuntzaren araberako oharmena al du elebidunak beste hizkuntzaren kudeaketan ere ? Esate baterako, zein puntutaraino dira elebidunon baliabide gaztelerazko / $\theta$ / edo frantsesezko /3/? Edo zein puntutaraino izan behar du batek elebidun horretarako ? Hori izan al liteke, bide batez, elebitasun mailaren neurgailu fonologiko?

Oharmen fonologikoari zuzenean eusteko : frantses-euskaradunak bokal gehiago bereizten al ditu gaztelera euskaradunak edo soilik euskaradunak baino euskara entzutean ere (frantsesak euskarak eta gaztelerak baino bokal gehiago bereizten dituelako, bokal inbentario luzeagoa duelako paradigman)?

\section{Oharmena eta paradigma-sintagma bikotea : hizkera mailak}

Paradigma esatean ezagutzaz ari naiz : gure memorian ditugun fonema kateak morfemaka edo unitate lexikoka bildurik. Hori oharmenaren esparru da. Gure hitzen barne egituraketan, batik bat, lehentasuna oharmena izan ohi da. Hitz edo morfemak oharmenaren araberako hotsetan (fonemetan) gordetzen ditugu. Horretarako paradigman oharmen garbia, hotsen arteko bereizkuntza onak bermatzen dituzten tasun eta kontrasteak dute lehentasuna.

Maila sintagmatikoan, alegia hotsen erabilera fisikoan, gauzak alderantzizkatu egiten dira. Hurrenez-hurreneko ontasunak indarra hartzean, hotsen ebakera erraztasuna da funtsezko eta ahultze bilakabideek (lenitioek) indarra hartzen dute.

Halaz ere, erabilera-maila batzuetan (zainduagoetan, formalagoetan), oharmena ere zaintzen da eta, horregatik, ahoskera hitzen aurkezpen paradigmatikoari atxikitzen zaio hizkera-maila arduragabeagoetan baino estuago.

Euskara aztertzetik ateratzen den ondorioetako bat bat hizkera maila guztietan gertatzen direla ordezkatze klase guztiak, zehazki, hizkera maila arduragabeetan berez zainduetakoak behar luketen oharmen zaintzaileak azaltzen direla.

Itxurazko paradoxa horren aurrean bi erantzun dira posible :

\footnotetext{
${ }^{5}$ Rosa Gandariasen bizkaiera eta Batuari bunzko lanak izan ziren honelakoen azterketa akustikoan aitzindari gure artean.
} 
a) Euskarak eta euskara bezalako hizkuntzek bereziki zaintzen dute hotsen oharmena, silaben arteko muga garbitasuna, eta abar.

b) Hizkuntzaren ibilbide soziologikoa da horren erantzule, alegia hizkuntza soziologikoki oso murriztua egon denez luzaroan, ez ditu nahikoa garatu hizkera ezberdinak, estilo eta mailen arteko kontrasteak.

Aukerok elkarren osagarri izan daitezke : ikertu egin behar da, bai euskaraz, bai teoria orokorrean eta baita beste hizkuntzetan ere.

\section{Oharmena eta ortografia}

Idaztea da hizkuntza kanporatu eta besterengana helarazteko beste modu bat. Dena den, idatzia ahoskeraren ondorengoa da : idatziak ahoskera islatzen du, letrek hotsak islatzen dituzte zuzen edo zeharka eta sistema alfabetikoak ezin dira hizkuntzaren sistema fonemikotik aparte ulertu.

Idatziari dagokiolarik oharmena da axola duena. Ekoizpenak, ahoskerak, berez, ez du axola : idatziak ahoskera horretatik hautematen duguna jasotzen du.

Hizkuntzaren ezagutza gramatikal, lexiko eta fonologikoa aintzat hartuta, baiezta dezakegu gero eta adostasuna handiagoa izan, "erosoago" gertatuko zaiola ortografiaren ohartzea erabiltzaileari.

Bestela, maila morfofonemikoa eta fonemikoa ez badatoz bat (gogora, esate baterako, errea /eria/ $\leftarrow / /$ errea//), ortografiak gehienbat aurkezpen morfofonemikora jotzen du.

Askotan idazkera morfofonemiko horiek neutralizazioren bat gertatu aurreko idazkera fonemikoak dira. Euskalkietan idatzia Batura egokitzean, behin baino gehiagotan egin da bide hori : ortografia fonemikotik (etxia) morfofonemikora (etxea) igarotzea ekarri du estandartzeak. Beste ortografia arautzeetan ere gertatu izan da hori. Adibidez, Ertaroko alemanean hitz beraren nominatiboa lant idazten zen (hitz azkeneko $\mathrm{d}>\mathrm{t}$ ahoskabetze neutralizazioagatik), genitiboa, landes. Orain, berriz, nom. Land ([lant]) / gen. Landes idazten da elementu morfologiko beraren aldagarritasun grafikoa gutxitzen duen arauagatik.

Esan bezala, Batua-aurreko ortografietan ez da hori beti hala izaten. Errepara, esaterako, ohe unitate lexikoaren agerraldiei ondoko aipuan :

Baionan zala uste zan Erramun, an arkitu zuten oian etengabeko mozkorrarekin, zatua eskuan zuala, oe guzia plai egiñik ; eta jendearen iskamilla somatzean deadar egiten omen zuan :

- Alto, kien bibe! Biba erpluika y benga biño!

(Pedro Miguel Urruzuno, 1910)

Batua, halere, ez zaio beti norabide berari jarraitu. Zenbait kasutan ortografi arauak maila morfofonemikoa baino kanporago dagoen maila fonemikoren bat hartu du eredu. Horrelakoetan besteetan baino handiago izan ohi da erabiltzailearen deserosotasuna : pentsa, baikara, baitzaio bezalakoez. Hiztunaren memorian eta aurkezpen lexikoan (maila morfofonemikoan) bera eta bakarra denaren aldakortasuna gertatzen da hor : gara / kara, zaio / tzaio.

Gainera, kasu honetan, posible da hiztunak zailtasunak izatea "bait" hori aurrizkitzat hartzeko. Egia da aurrizki gutxi dituela euskarak pareko egiteko morfosintaktikoetan ; baita ere erlatiboki aurrizki gutxi sortzen dituen hizkuntza dela. Oro har, beste hizkuntzetan ere, aurrizkiak ez dira atzizkiak bezain erraz 
eratzen (labur esanda, preposizioek luzaroago irauten dute aurrizki bihurtu gabe, postposizioek atzizki bihurtu gabe baino). Horren ondoan, aintzakotzat hartu behar dugu idazkera fonemikoaren esparrua hitza izaten dela (latinezko preposizioa ez zen inoiz "im" idatzi, nahiz eta aurrizkia sistematikoki "im-" idatzi zen ezpainkarien aurrean), ziurrenik idaztearen moteltasun handiagoagatik. Stampek esaten duen bezala, ortografia fonemak hitzez hitz ahoskatuz egin bide da.

Horregatik guztiagatik arruntak dira biyotza, mendiya, etxia edo biyar egin biar degu bezalako idazteak. Gutxiagotan gertatzen dira eztegu bezalako kanpo sandhien eraginak eta, orduan, elkarturik idazteko joera dago (hitz bakartzat hartzekoa, alegia).

\section{Oharmena eta bertsogintza}

Fonemarik gabe hankamotz geratzen zaigun beste alor inportante bat da hau. Bide batez eta horren osagarri, fonologiaren ulertzeko oso ikerreremu emankorra izan daiteke eta euskarak oparo duena. On litzateke, bai euskararen estudioetarako eta baita fonologi teoriaren aurrerapenerako ere, gure arteko ikerlariak bide honetan barrena abiatzea.

Izan ere, bertsoan eta musikan, axola duena aldi bakoitzeko benetako ahoskera (zehazki esan, ahoskera horren oharmen fonemikoa) da eta ez analisi morfofonemikoa. Neurriak eta puntuak behar bezala funtzionatuko badute, inportante direnak ez dizkiote irakurleari libre uzten bertsolari eta poetek, idazkera ortografiko morfonemiko arruntak aukerak emango lituzkeenean (Maitea, tristea, zu zera nerea idazkera kanonikoan libreegi da : cf. Maitia tristia, zu zera neria). Ematen du idazlea ez dela irakurleaz fio. Horregatik irakurtzeko ematean (poesiak edo bertso paperak) edo kantatua jasotzean, honelakoak aurkitzen ditugu :

Erantzungo'izut ikusiya naiz

makinatxo bat peri ta,

zu ez al zaude ni nola nagon

kontura ongi erorita?

Uztapide, 1969

Lehenengo lerroko "d" ez idatziak "o" eta "i" silaba bakarrean ahoskatzea ziurtatu nahi duelarik.

Hortan e zorionik

ez bide da nihun, neskatxak, nahi dauzuet

hauxet erran egun :

koblari hartzen bauzue

zuen bizi-lagun, zonbeit gau beharko'uzue

pasatu alargun

Mattin, 1960

Hemen "ere" hitzak, horrela idatzirik, honako aukerak izango lituzke : ere, ee, e ; denak ere fonemikoak, noski, baina bakarra da neurri beharretara egokitzen dena. 
Horregatik poesian ere aurki genitzakeen "lotze" fonemiko zehatzok. Kasu hau silaba bakarrean ahoskatu beharra markatzearen adibide da.

Errima lotzeko ere zaintzen da idazkera, gorago ikusi bezala (maitea / maitia). Halaber Lasarteren honetan :

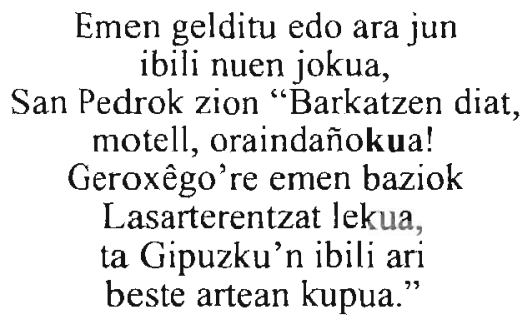

Lasarte, 1969

Nahiago dira morfofonemikoki eta fonemikoki bat datozen errimak, nahiz eta adostasun fonemikoa bakarrik nahikoa den. Nahikoa dela ikusten da, goikoan bezala, Xalbador-ek 1960an kantatutako bertso hauetan :

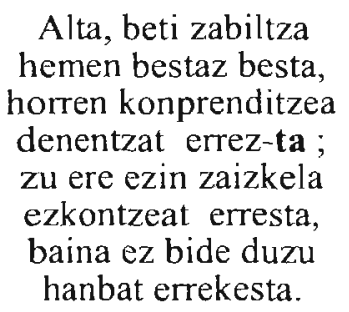

Hemen ere errima ez da morfofonemikoa, fonemikoa baizik -laugarren lerroko [ta] hori morfofonemikoki //da// da, fonemikoki, ordea, /ta/ eta nahikoa da hori errimari eusteko--.

Badira, dena dela, aztertzeko gelditzen diren arazoak. Berdintasun fonemikoak ez dirudi beti orain arteko adibideetan bezain sendo, morfofonemikoki desadostasuna denean. Esaterako, hori da / hirira ez litzateke puntu ona bokalarteko "d" " $r$ " bezalaxe eginda ere : [orira / irira]. Hemen lenitio edo ahultzea jazotzea (hala bada : merezi luke hori ere eztabaidatzea), goragokoetan fortitioa genuen bitartean izan daiteke konponbidearen osagai bat. Ez dugu aski ikertu hipotesian aurrera egiteko.

Fonemak ala fonema klaseak diren errima-euskarri hartzen direnak ere izan liteke beste ikerbide interesgarri bat. Fonemak baino fonema klaseak erabiltzen direla nahiko garbi dirudi hots txistukarien adibide batzuetan. Dirudienez ahoskune ezberdinek berdin balio dute. Ahoskune ezberdinek eta apikari-bizkarkariek klase bakarra osa dezaketela ematen du, esaterako, Xalbadorrengandik jasotzen ditudan latsak, meskatxak, aberatsak lerro azkenetan. Errepara, halaber, goraxeagoko bertsoan ; besta, erresta, errekesta /errez-ta. 
Beraz, beti ere fonema edo fonema klaseak dira erabiltzen direnak. Diferentzia azpifonemikoak (alegia diferentzia fonetikoki badagoenenan, baina fonemikoki ez) ez du axola, ez delako hautematen, oharmena fonemikoa delako eta ez fonetikoa. Horregatik, ondorengoetan [d] / [ð] diferentzia fonetikoak ez du inolako trabarik egiten, biak fonemikoki /d/ baitira :

han zegoen dama $([\mathrm{d}])$

hura bai madama ([ð])

\section{Fonetika eta fonologia, berriro}

Gorago esan da oharmena aintzat hartzen ez bada, fonetika ezin dela izan fonologiaren bigarren mailako laguntzaile besterik. Orain arte ikusitako adibideetan, ematen du fonologiak fonetika ukatzen duela. Nolabait gure hizketaren erabileran, bertsogintzan, eta abarretan izaera fonologikoa (fonemikoa) ez duenak ez duela axola. Baina hori fonologiko/fonetiko parea zentzu estu eta agorrean hartzea litzateke. Izan ere, oinarriaren oinarrira jota ere, pentsatu behar da hizkuntzen fonema aukeretan ere ekoizpen indar fonetikoek badutela zeresana. Hizkuntza bakoitzaren fonema inbentarioaren aukera eta hierarkiak ekoizpenerako elkarrekin ongien datozen tasunak erabiltzen dituzte -esaterako, hersketa ahoskabetasunarekin : horregatik dituzte hizkuntza guztiek herskari ahoskabeak--). Alde horretatik lasai aldarrika dezakegu fonologiaren oinarri eta funtsa fonetikoa dela : nolabait, zilegi bazait : fonologia fonetika da, fonetika hautatua, fonetika "antolatua".

Fonologia (berdin jakintza zein hiztunaren ahoskera-gaitasuna) ezin dela fonetikatik banatu berriro aldarrikatzeko, Doneganen (1996) atalez-ataleko eskemaren zati bati jarraituko natzaio :

1) hizkuntzetako fonema sistemen lege unibertsalak ebakera eta oharmen gaitasunen araberakoak dira : fonema sistemen lehentasunek ahoskagarritasuna eta ikasterraztasuna islatu ohi dituzte (alegia ez dira halabeharrez $/ \mathrm{p}, \mathrm{t}, \mathrm{k} /$ usuago gertatzen munduko hizkuntzetan klikak baino edo eiektiboak baino, are /c/ bera baino...

2) hizkuntzen ordezkatze fonologikoen emankortasuna handitu edo gutxitu egiten da mailaketa edo hierarkia fonetikoaren arabera (alegia, ez da halabeharrez /g/ bokalartean gehien "jaten" duguna, /d/ gutxiago eta /b/are gutxiago...

3) ordezkatze fonologikoen gertakortasuna errealitate fonetikoen araberakoa da (errealitate fonetiko linguistiko zein ez-linguistikoak barne) eta ezin dira ahaztu :

- ordezkatzen denarekin batera inguruan dauden beste tasunak (bereizle zein ezbereizle) : cf. bider [biðer] bustikuntzarik gabea eta inder [ißfer] bustia, bigarren "d" herskari da, halaber palataltasun gehiago dago ingurunean.

- baldintza prosodikoak (dudarik gabe hori esan aldiaren baldintza, egoera fisikoa da).

- baldintza ez-linguistiko edo paralinguistikoak, ahoskatzen ari den (eta entzuten ari den) gorputzaren baldintzak.

\section{Amaitzeko}

Ez dakit nahikoa aipatu dudan, baina hango eta hemengo euskaren azterketa egitea biziki argigarri gertatuko zaigu euskararen ezagutzarako eta baita, 
oharmenaren sakontze teorikorako ere. Hangoak hangoa eta hemengoek hemengoa aztertzea on izango da, baina batik bat elkarren arteko zubiek emango digute erkaketak egiteko aukera eta, horrela, gauzen ezagutzan axaleko anekdotetatik, ahoskeraren funtsezkoetara igarotzeko bidea. Izan daitezela honelako mintegiak gure arteko harremanak hasi, segi eta sendotzeko oin.

\section{Erreferentziak $^{6}$}

Chomsky, Noam. 1964. Current Issues in Linguistic Theory. The Hague : Mouton.

Donegan, Patricia. 1996. On the relation between phonetics and phonology. 29th Meeting of the Societas Linguistica Europaea. Universität Klagenfurt, 48.IX.1996-an aurkeztu txostena.

García Calvo, Agustín. 1989. Acercamiento al lenguaje por vía del oído. Hablando de lo que habla. Estudios de Lenguaje. Madrid : Lucina, 65-85.

Halle, Morris. 1959. The Sound Pattern of Russian. The Hague: Mouton.

Jauregi, Oroitz / Miren Lourdes Oñederra. (moldiztegian). Comprobación fonética de las sospechas fonológicas (y viceversa). Actas del II Congreso de Fonética Experimental. Universidad de Sevilla, 5-6-7 de marzo de 2001.

Oliver Sacks. 1996. To see and not see. An Anthropologist on Mars. New York : Vintage Books, 108-152.

Sapir, Edward. [1933] 1968. La réalité psychologique des phonèmes. Linguistique. Paris : Les Éditions de Minuit, 165-203. /[1949] 1978. The psychological reality of phonemes. Phonological Theory. Evolution and Current Practice. Valerie Becker Makkai, ed. Lake Bluff : Jupiter Press, 2231.

Saussure, Ferdinand de. 1916. Cours de Linguistique Générale. Paris : Payot.

Stampe, David. 1987. On phonological representation. Phonologica 1984.Wolfgang U. Dressler, Hans C. Luschützky, Oskar Pfeiffer, John Rennison, eds. London: Cambridge University Press, 287-300.

Stampe, David. ms. "Yes, Virginia ...".

\footnotetext{
${ }^{6}$ Bertsolarien adibideak Auspoa bildumatik hartuak dira.
} 